\title{
Türkiye'deki Suriyeli Göçmen Nüfus İçin Yaşam Alanı Seçimi
}

\author{
Gonca ÇETİNKAYA EROĞLU1, Nehir VAROL²
}

\begin{abstract}
Özet
21. yüzyılın en büyük kitlesel göçü olarak tanımlanan Suriyeli göçünün 11. yılında kamplardaki yașamlarını sonlandırarak Türkiye'nin her şehrinde dağınık halde yaşamayı tercih eden Suriyeli göçmen nüfus için yaşam alanlarının belirlenmesi gerekliliği ortaya çıkmaktadır. Bu nedenle çalışmada Türkiye'deki Suriyeli göçmen nüfus için ekonomik, sosyal, kültürel ve güvenlik sorunlarını azaltmayı hedefleyen sürdürülebilir yaşam alanlarının belirlenmesi amaçlanmıştır. Kuramsal anlamda göç teorileri, göçün nedenleri sonuçları, göç ve afet ilişkisi incelenmiştir. Çalışmada pandemi kısıtları nedeniyle 33 kişilik örneklem grubuna ulaşılabilmiş katılımcıların toplumdaki uyumu, Türkiye'den beklentileri ve kalıcılıkları göz önünde bulundurularak sosyo-demografik ve sosyo-ekonomik özellikleri analiz edilmeye çalışılmıştır. Ayrıca çalışmanın konusu gereği katılımcılardan yaşam alanlarından beklentilerinin sıralanması istenmiştir. Sanılanın aksine Türklerin yoğun olduğu bölgelerde yaşamayı tercih eden katılımcıların en büyük sıkıntının ekonomik anlamda yaşandığı gözlemlenmiștir.
\end{abstract}

Anahtar Kelimeler: Göç, Suriyeli Göçü, Göçmen Yaşam Alanları, Afet

\section{Living Area Selection for the Syrian Migrant Population in Turkey}

\begin{abstract}
In the 11th year of the Syrian migration, which is defined as the biggest mass migration of the 21st century, it becomes necessary to determine the living spaces for the Syrian immigrant population, who prefer to live in a dispersed form in every city of Turkey by ending their lives in the camps. For this reason, in this study, it is aimed to determine sustainable living spaces that aim to reduce economic, social, cultural and security problems for the Syrian migrant population in Turkey. In the theoretical sense, theories of migration, the causes and consequences of migration and examples of migration in the world have been examined. In the study, it was tried to analyze the socio-demographic and socio-economic characteristics of the participants, who were able to reach a sample group of 33 people due to the limitations of thepandemic, taking into account the adaptation of the participants in the society, their expectations from Turkey and their permanence. In addition, according to the subject of the study, the participants were asked to list their expectations from their living spaces. Contrary to popular belief, it has been observed that the participants who prefer to live in regions where Turks are densely experiencing the biggest problem in terms of economy.
\end{abstract}

\footnotetext{
$1^{*}$ Ankara Üniversitesi, Afet Risk Yönetimi Bölümü, Ankara

İlgili yazar e-posta/ Corresponding e-posta/e-mail: goncacetinkaya@hotmail.com ORCID No: 0000-0002-3158-6900

${ }^{2}$ Ankara Üniversitesi, Afet Risk Yönetimi Bölümü, Ankara

e-posta/e-mail: nehir.varol@gmail.com ORCID No: 0000-0003-4876-9313
} 
Keywords: Immigration, Syrian Migrant, Living Area for Immigrants, Disaster

\section{GİRIŞ}

İnsan varoluşundan bu yana ekonomik, siyasi, sosyal, kültürel, coğrafi vb. nedenlerden dolayı göç etmiş veya göç etmeye zorlanmıştır. Uluslararası Göç Örgütünün yaptığı tanıma göre göç, bireylerin uluslararası bir sınırı geçerek veya bir devlet sınırları içerisinde yapmış olduğu yer değiştirme eylemi olarak tanımlanmıștır (IOM, 2011). Birleşmiş Milletler Göç Örgütü'nün 2020 yılında yayınladığı Dünya Göç Raporuna göre dünya üzerinde 272 milyon göçmenin yaşadığı ve tüm dünya nüfusuna oranlandığında her 30 kişiden birinin göçmen olarak hayatına devam ettiğinden bahsedilmektedir (IOM, 2020).

İnsanların yaşam koşullarını daha iyiye taşıma güdüsü uluslararası göçmen sayısının son otuz yılda \%78 oranında artışının nedenlerinden biri olarak açıklanabilir. Fakat bu artışta maalesef kariyer, eğitim gibi sebeplerle gönüllü göç edenlerin dışında 2011 yılından bu yana Orta Doğu ve Kuzey Afrika'ya yayılan Arap Baharı' nın etkisiyle göç etmek zorunda kalan göçmenlerin payı büyüktür. 17 Aralık 2010 günü Tunuslu bir gencin pazar yerinde kendini ateşe vermesiyle başlayan ve işsizlik, enflasyon, yolsuzluk, ifade özgürlüğü gibi pek çok sorunu protesto etmek amacıyla yapılan gösteriler yüzbinlerce kişinin ölümüne, milyonlarca kişinin göç etmesine sebep olmuştur. İç savaşa dönüșen protestolar sonucu sadece Suriye'de 23 milyon olan ülke nüfusunun yaklaşık 6,5 milyonu (\%33'ü) ülke dişına göç etmek zorunda kalmıștır. Son yüzyılın en büyük insan hareketi olarak tanımlanan bu göçte yaklaşık 4 milyon Suriyeli göçmen Türkiye 'ye sığınmıştır (GİGM, 2020).

Göç başta birey olmak üzere insana dair olan inanç, düşünce, kural ve yapıların değişim ve dönüşüm yaşamasına zemin hazırlamaktadır. Bu değişim ve dönüşümden terk edilen ve yerleşilen yeni mekânla birlikte, bu mekândaki insanlar ve insana dair olan her ne varsa onlar da nasibini almaktadır (Ekici ve Tuncel, 2016). 2011 yılından bu yana en fazla Suriyeli göçmene ev sahipliği yapan Türkiye'de bu değişim ve dönüşüm sürecinden geçmektedir. Ülkemize giriş yaptıklarından itibaren barınma, yiyecek, sağlık ve eğitim ihtiyaçları sığınma kampları tarafından karşılanan Suriyeli göçmenlerin \%98'i maksimum 6-8 ay sonra bu kampları terk ederek kentlerde yaşam mücadelesi vermeyi tercih etmektedir. Okuma-yazma oranı düşük, herhangi bir mesleki yetkinliği bulunmayan veya az bulunan, yaş ortalaması 22 olan ve en önemlisi Türkiye nüfusunun $\% 4,4$ ' ünü oluşturan göçmen nüfus, Türkiye'nin her şehrinde dağınık ve bazı şehirlerinde yoğun biçimde yaşamaktadır.

$\mathrm{Bu}$ çalışma ile kentlerde ekonomik zorluklar, güvenlik endişeleri, sosyal ve kültürel uyumsuzluklar başta olmak üzere pek çok sorunla karşı karşıya kalan ve ülkelerine dönme umutları günden güne azalan Suriyeli göçmenlerin yaşam koşullarını optimize edecek yaşam alanlarından beklentileri değerlendirilmiştir.

\section{GÖÇ}

Toplumdaki yapısal değişiklikler, aynı zamanda toplum, kültür ve ekonomideki fırsat ve sorunları gizlerken, toplumsal tabakalaşmayı hızlandırmıştır. Göçmenlerin yeni yaşam alanlarına uyum sağlayabilmeleri sosyal sınıf veya benzer özelliklere sahip sınıflarla güçlü dayanışma içinde birlikte hareket etmelerine bağlıdır. Yüksek düzeyde dayanışma ve risk alma, göçmenlerin güçlü yenilenme potansiyeline sahip dinamik bir yapıya sahip olmalarına ve kendilerine yeni firsatlar yaratmalarına katkıda bulunur (Ekici ve Tuncel, 2015). 
Tarihte kitlesel olarak yapılan göç hareketlerinin göç edilen yerde ekonomik, siyasi, sosyal ve kültürel anlamda olumlu ya da olumsuz dalgalanmalara sebep olduğu görülmüştür. Küreselleşmenin de etkisiyle birey hareketliliğinin arttığı günümüzde ülkeler, olumsuz sonuçlar doğurmaması için mevcut sistemi koruyacak, göçmenler ve yerel halk arasında çatışmaların oluşmasına izin vermeyecek, gönüllü ya da gönülsüz göç etmiş tüm bireylerin yaşam haklarını savunacak hem ulusal hem uluslararası düzeyde yasalar koyarak göçmenlik olgusuna hukuksal çerçeve oluşturmuşlardır. II. Dünya Savaşı sonrası savaştan kaçan toplumlar için 1951 yılında "Birleşmiş Milletler Mültecilerin Hukuki Statüsüne İlișkin Cenevre Sözleşmesi" düzenlenmiş, 1967 yılında da New York protokolü ile kapsamı genişletilerek "1 Ocak 1951 'den önce meydana gelen olaylar sonucunda" ifadeleri çıkarılarak ilk sözleşmede bulunan zamansal sınırlama kaldırılmıștır. Türkiye sözleşmeleri imzalayan 147 ülkeden biri olarak "coğrafi sınırlama" şartını saklı bırakmıştır. "Coğrafi Sınırlama” şartı ile Avrupa Konseyi üyesi ülkeler dışından gelen iltica etmek isteyen kişilere geçici uluslararası koruma sağlanarak mülteci statüsü verilmemektedir (MülteciDer, 2019). Geçici koruma, Türkiye'deki Suriyelileri tanımlamamıza yardımcı olmaktadır. Bu terim kitlesel göç durumunda acil çözümler bulmak için tasarlanmış bir koruma şeklidir. Ulusal geri göndermeme yükümlülüğü çerçevesinde büyük çapta ulusal sınıra ulaşan kişiler için kişisel kimliklendirme süreçleriyle vakit kaybetmeden uygun pratik bir ek çözümdür (GİGM, 2015).

\section{GÖÇ VE AFET}

Afetler ve göç arasındaki ilişki sebep sonuç ilişkisi olarak görülse de göç tek başına, afet türleri arasında insan kaynaklı afetler başlığı altında incelenmektedir. Ekonomik, siyasal, sosyal ve ya kültürel sebeplerin yanı sıra deprem, iklim değişikliği, tsunami vb. gibi doğa kaynaklı afetler sebebiyle de pek çok insan göç etmek zorunda kalmaktadır. Sadece 2018 yılında 144 ülkeden 17,2 milyon insan doğa kökenli afetler nedeniyle yer değiştirmiştir. Hindistan'da Bihar'daki sel nedeniyle 1,6 milyon kişi, Hipokampus tropik kasırgaları ve nehir taşkınları nedeniyle Çin'de yaklaşık 4 milyon kişi ve Filipinler'de periyodik şiddetli yağışlar ve toprak kaymaları nedeniyle yaklaşık 4 milyon kişi yer değiştirmek zorunda kalmıştır (IDDMC, 2019). Birleşmiş Milletler Kalkınma Programı tarafından yayınlanan rapora göre, 2016 yılındaki en büyük 10 göç akışına iklim değişiklikleri neden olmuştur. Aynı rapor, 2050 yılına kadar dünya çapında 200 milyon insanın iklim değişikliği nedeniyle yer değiştirmek zorunda kalacağından bahsetmektedir.

Her insanın belirli bir uyum kapasitesi vardır. Bu uyum kapasitesini bir yaya benzetebiliriz. Yayı çektiğiniz zaman, yayın bir esneme derecesi vardır. Eğer direncinin üzerinde bir çekme kuvveti uygulanırsa yay kopar. İnsanın da çevre koşullarına uyumu sınırsız değildir (Varol ve Gültekin 2016). Günümüzde kuraklıklar, aşırı yağışlar, sıcak hava dalgaları, yıkıcı kasırgalar gibi aşırı iklim olayları doğrudan veya dolaylı olarak can almakta, Orta Doğu ve Kuzey Afrika'dan Avrupa'ya ve Orta Amerika'dan ABD’ye doğru milyonlarca kişiyi evlerinden göç etmeye zorlamaktadır. Bu göç hareketleri küresel ölçekte siyasi ve sosyal hareketleri ivmelendirecek domino taşı etkisi yaratmaktadır. Geçtiğimiz yıl Amerika 'da iklim değişikliği ile zorunlu göçler arasında bağlantı olduğunu savunan bilim insanlarını destekleyen bir proje başlatılmıştır. Proje kapsamında iklim muhabiri Abrahm Lustgarten, yazdığı makalede göç araştırmacılarına daha yakından bakıldıkça neredeyse her yerde iklimin parmak izlerinin bulunacağından bahsetmiștir. Kuraklığın, birçok Suriyelinin savaştan önce şehirlere itilmesine neden olduğu ve gerginlikleri arttırdığı ayrıca mahsul kayıplarının işsizliğe yol açarak Mısır ve Libya'da Arap Baharı ayaklanmalarına neden olduğu belirtmiştir. Brexit 'in bile tartışmalı olsa da Arap Baharı'nın yol açtığı çatışmalardan tetiklenerek Avrupa'ya yayılan kitlesel göçün yan etkisi olduğunu ileri sürmüş ve tüm etkilerin başlangıcını sadece iki milyon insanın hareketiyle ilişkilendirmiștir (Lustgarten, 2019).

Genel olarak doğa veya insan kökenli afetlerin sonucu olarak kabul edilen göç, aslında sebebine bakılmaksızın kendi başına insan kökenli bir afet türüdür. Fiziksel, sosyal ve ekonomik kayıplar doğuran, normal yaşamı kesintiye uğratan, hem göç eden toplumu hem mevcut yaşayan toplumu 
etkileyen ve ikincil afetlere de neden olabilecek güçte bir olgudur. Örneğin kötü koşullarda barınma ve yetersiz beslenme sonucu oluşan bulaşıcı hastalıklar, tarım alanlarının amaçları dışında kullanılması sonucu oluşan kıtlık, nüfus yoğunluğundan meydana gelen çevre ve hava kirliliği ilk akla gelen ikincil afetlerdir. Uzun vadede ise ekonomik, sosyal ve psikolojik olarak yerel halkla entegrasyonu sağlayamamış göçmen toplulukların dışlanma psikolojisi ile gettolaşması ve toplumda güvenlik endișelerine yol açan olaylara hatta terör saldırılarına sebebiyet vermesi de ikincil afet olarak değerlendirilebilir.

\section{TÜRKIYE'NİN GÖÇ TARİHİ}

Türkiye için göç hareketleri bağlamında bir sınıflandırma yapıldığında göç alan, göç veren ve daha önemlisi tarihi boyunca göç yolları üzerinde transit geçiş ülkesi konumunda bulunduğu söylenebilir (Baykal ve Yılmaz, 2020). İlk olarak Osmanlı İmparatorluğu'nda sosyal, siyasi, ekonomik sebeplerle yapılan göçlerin günümüz Türkiye'sinde de devam ettiği görülmektedir. Özellikle II. Dünya Savaşı ve sonrasında soğuk savaşta olduğu gibi uluslararası yaşanan olayların göç hareketliliklerine ve dolayısıyla Türkiye'ye etkisi çok fazladır. Sahip olduğu jeopolitik konumdan ötürü hem Cumhuriyet öncesi hem de Cumhuriyet sonrası dönemde savaş, mübadele, siyasi ve ekonomik istikrarsızlık başta olmak üzere çeşitli nedenlerle göç eden topluluklara ev sahipliği yapmıştır.

Türkiye'nin tarihi boyunca yaşadığı üç önemli göç hareketi olmuştur. Birincisi, I. Dünya Savaşı sırasında Balkanlarda yaşayan Türklerin oluşturduğu göç hareketidir. İkincisi, Körfez Savaşı sırasında bölgeden kaçan Iraklı göçmenlerin Türkiye’ye sığınmasıdır. Üçüncü ve en büyüğü ise Arap Baharı sonrasında Suriye'de çıkan iç savaştan kaçarak Türkiye'ye sığınan Suriyeli göçmenlerin göç hareketidir. Cumhuriyet dönemi sonrası oluşan göç hareketlerini aşağıdaki gibi siralayabiliriz.

- 1922-1938 yılları arasında Yunanistan 'dan 384 bin kişi,

- 1923-1945 yılları arasında Balkanlar 'dan 800 bin kişi,

- 1933-1945 yılları arasında Almanya 'dan 800 kişi,

- 1988 yılında Irak 'tan 51 bin 542 kişi,

- 1989 yılında Bulgaristan'dan 345 bin kişi,

- 1991 yılında I. Körfez Savaşı' ndan sonra Irak'tan 467 bin 489 kişi,

- 1992-1998 yılları arasında Bosna 'dan 20 bin kişi,

- 1999 yılında Kosova 'da meydana gelen olaylar sonrasında 17 bin 746 kişi,

- 2001 yllında Makedonya 'dan 10 bin 500 kişi,

• Nisan 2011- Ekim 2020 arasında Suriye 'de yaşanan iç karışıklıklar nedeniyle yaklaşık 3,6 milyon kişi (GİGM, 2019).

Cumhuriyetin ilk yıllarında ulus devlet olma yolunda nüfusun millileştirilmesi için kabul edilen Türk-Yunan mübadelesiyle başlayan Balkan göçü, 1989 yılında Bulgaristan 'da yaşayan Türklere yönelik baskıların artması ile devam ederek 1992-1998 yılları arasında Bosna Savaşından kaçan soydaşlarımızla son bulmuştur. Bu süreci hem göç eden toplum hem ev sahibi toplum bakımından sosyal ve kültürel açıdan uyum sorunu yaşanmayan, ekonomik sıkıntıların zamanla aşıldığı, güvenlik sorunlarının neredeyse hiç yaşanmadığı düzenli bir göç süreci olarak tanımlayabiliriz. Ülkemiz bu sayede göç, göçmenlik ve ev sahibi ülke olma konularında tecrübeler edinmiş olsa da 2011 yılından bu yana devam eden düzensiz Suriyeli göçünü yönetmek hiç de kolay olmamıştır. Dil birliğimizin olmadığı, sosyal ve kültürel uyum sorunu yaşanılan, sayıca diğer göçlerle kıyaslanamayacak yoğunluktaki Suriyeli göçünde, ekonomik, sosyal, kültürel ve güvenlik bakımlarından pek çok sorun ortaya çıkmıştır. 
$\mathrm{Bu}$ büyük göç dalgasıyla tek başına mücadele eden ve gelişmiş ülkelerden yeterince yardım alamayan Türkiye, 3 milyonu aşkın göçmenin beslenme, barınma, eğitim ve sağlık sorunlarına çözüm bulmaya çalışırken bir yandan da idari reformlar yapmaktadır (Efe, 2018). Bu nedenle ülkemizin 1951 Cenevre Sözleşmesi ve 1967 New York Protokolü'ne taraf olarak uluslararası standartlara uygun etkin bir ulusal sığınma sisteminin kurulması için yasal ve kurumsal reformlar yapması gerekmektedir. Nisan 2013'te Türkiye'nin ilk iltica yasası olan Yabancılar ve Uluslararası Koruma Yasası Türkiye Büyük Millet Meclisi tarafından onaylanmış ve 11 Nisan 2014'te yürürlüğe girmiştir. Bu yasa ile Türkiye'nin ulusal iltica sisteminin temelini atılmış ve Göç İdaresi Genel Müdürlüğü kurulmuştur. 29 Ekim 2021 tarihinde 85 numaralı Cumhurbaşkanlığı kararnamesi ile Genel Müdürlüğün statüsü başkanlık olarak değiştirilmiştir.

\subsection{Türkiye'ye Suriyeli Göçü}

18 Aralık günü Tunus 'ta halkın sokaklara dökülmesiyle başlayan Mısır, Libya, Suriye, Yemen gibi diktatör rejimle yönetilen Arap ülkelerinde iç karışıklığa Suriye 'de ise savaşa dönüşen çatışmalar sonucu 400 binden fazla kişi hayatını kaybetmiş, milyonlarca kişi evlerini terk etmek zorunda kalmıştır. 2011 yılının Ocak ayından günümüze kadar 22 milyon Suriye nüfusunun yarısından fazlası evlerini, 6.5 milyonu aşan Suriyeli ise ülkesini terk etmek zorunda kalmıştır. Bu göçmenlerin 3 milyon 639 bini Türkiye'de, 944 bin 200'ü Lübnan'da, 676 bin 300'ü Ürdün'de yaşamaktadır. Buna karşın Avrupa Birliği 'ne üye ülkelere bakılacak olursa Almanya'da 532 bin 100, İsveç'te 109 bin 300, Avusturya' da 49 bin 200, Hollanda 'da 32 bin 100 Suriyeli göçmen yaşamaktadır (UNHCR, 2020).

Suriyelilerin Türkiye'ye akını Nisan 2011 'de başlamıştır. Türkiye, o tarihten itibaren Suriyeliler için "açık kapı politikası" ilan etmiş ve 100.000 kişinin kritik bir eşikte olduğunu, ancak Suriye'den gelen göçmen dalgasının beklentileri aştığını belirtmiştir (Orhan ve Gündoğar, 2015). Bu süreçte artan göç dalgasının kontrolü zorlaşmıştır. İçişleri Bakanlığı Ekim 2011'de Türkiye'de kayıtlı Suriyelilere "geçici koruma statüsü" verilmesi yönünde bir karar almıştır. İlk gelen Suriyelilerin kampa yerleştirilmesinin ardından Suriyeliler kendi tercih ve çabalarıyla Türkiye'ye dağılmaya başlamıştır.

\subsection{Suriyeli Göçmenlerin Yaşam Koşulları}

Ülkemizde geçici koruma altındaki göçmen nüfusunun \%89'u Suriyeli göçmenlerden oluşmaktadır. Çalışmada Suriyeli göçmenlerin demografik yapılarının irdelenmesi üzerine yoğunlaşmanın yaşam alanları seçiminde fayda sağlayacağı düşünülmüştür. Türkiye 2011 yılından bu yana savaştan kaçmak zorunda kalan Suriyeli göçmenlerin savaş bitince ülkelerine dönecekleri beklentisiyle acil ihtiyaçlara yanıt veren ve zorla geri gönderilmelerine karşı koruma sağlayan "geçici koruma" statüsü verilmektedir. Fakat bu beklenti yerini Suriye'de ne zaman biteceği öngörülemeyen iç karışıklık nedeniyle ülkemizin çabalarıyla oluşturulmaya çalışılan güvenli bölgeye rağmen dönüşlerin göçmen nüfusunun $\% 20$ 'sini aşmayacağı gerçeğine bırakmıştır. T.C. Sağlık Bakanlığının yayınladığı verilere göre son sekiz yılda Türkiye 'de doğan Suriyeli bebek sayısının 450 bini aştığı göz önüne alınırsa geçici koruma statüsünde bulunan göçmen nüfusunun önümüzdeki yıllarda da azalmayacağı kaçınılmazdır.

16 Aralık 2020 itibariyle Türkiye'de bulunan Suriyeli göçmenin \%1,6 'sı Hatay, Kilis, Adana, Kahramanmaraş ve Osmaniye'de bulunan kamplarda yaşamaktadır. Kalan 3.580.667 kişi ise İstanbul (517.345) başta olmak üzere Gaziantep (450.611), Hatay (433.012), Şanlıurfa (421.367) ve Adana (251.634) gibi büyük kentlerde ikamet etmektedir. Kilis ili örneğinde olduğu gibi bazı kentlerde göçmen yoğunluğunun il nüfusunun \% 76 'sına ulaşması dikkat çekecek kadar fazladır (GİGM, 2020).

Geçici koruma kamplarından maksimum 6-8 ay kaldıktan sonra kentlerde yaşamayı tercih eden göçmenlerin yerleşim yeri seçimleri kendiliğinden gelişmekte herhangi bir devlet kurumu ve ya STK yönlendirmesi bulunmamaktadır. Suriyelilerin yerleşim yeri tercihlerinde geçimlerini 
sağlayabilecekleri ve çalışma olanakları görece daha iyi olan yerleri daha ziyadesiyle tercih ettikleri bulgulanmıştır (Çalışkan, 2020). Genellikle aile, akraba ve ya arkadaş vasıtasıyla seçilen bu kentlerde yaşam, kayıt dışı ve günlük işlerden edinilen düşük gelirlerle çok daha zor olmaktadır. Genellikle büyük kentlerde yaşayan Suriyeliler gecekondu, apartman bodrum veya teras katları, çadırlar, konteynırlar hatta terkedilmiş yıkık binalarda beslenme, güvenlik, temizlik vb. gibi sorunlar ile başa çıkmaya çalışarak yaşamlarını sürdürmektedir.

\section{ANALİZ}

Çalışmada Türkiye 'de yaşayan Suriyeli göçmen nüfus için yaşam alanı seçimi ile ilgili olarak anket çalışması yapılmıştır. Yapılan anket ile ülkemizde kampta ya da kamp dışında yaşayan Suriyeli göçmen nüfusun demografik yapıları, ekonomik durumları, ülkemizdeki yaşam standartları, ihtiyaçları ve ülkemizden beklentilerinin ölçülmesi hedeflenmiştir. Çalışmanın evreni Türkiye'de yaşayan yaklaşık 4 milmon Suriyeli göçmen nüfus olup anket çalışmamız Covid-19 salgını nedeniyle oluşan sınırlılıklardan dolayı 33 kişi ile yapılmıştır. 24 sorudan oluşan anket çalışması salgın kısıtlamaları nedeniyle yüz yüze yapılamamıştır. Soruların 1 tanesi derecelendirme sorusu olup kalan 23 soru çoktan seçmeli olarak hazırlanmıştır. Anket soruları üç ana gruba ayrılmıştır: İlk kısım katılımcıların sosyo-demografik ve ekonomik özellikleri, ikinci kısım Türkiye 'deki yaşam koşulları ile uyum problemleri ve üçüncü kısım Türkiye 'den beklentilerini ortaya çıkarmaya yönelik sorulardan oluşmaktadır. Araştırma sürecinde elde edilen verilerin işlenmesi ve çözülmesi elde edilecek verilerin anlam kazanmasında önem arz etmektedir. Frekans ve yüzde analizleri grafiklerle gösterilmeye çalışılmış, bazı değişkenler arasındaki ilişkinin varlığını göstermek amaciyla çapraz tablolar oluşturulmuştur.

\section{BULGULAR}

Anket çalışmasında katılımcıların araştırma evrenine paralel olarak Kadın/Erkek dağılımının neredeyse eşit olduğu (Şekil 1) fakat yaş grubunun 18-30 yaş aralığında yoğunlaştığı görülmektedir (Şekil 2).

Bu nedenle araştırma grubumuzun \%76 'sının lise ve üstü eğitim aldığı gözlemlenmiștir (Şekil 3). Yaş ortalaması düşük olan katılımcıların Suriye'de öğrenci olma oranı \%58 olması, eğitim hayatları devam ederken Türkiye'ye gelenlerin çoğunlukta olduğunu göstermektedir. Türkçe yeterlilik seviyesinin de iyi/çok iyi olarak belirtenlerin oranının yüksek olması (\%79) ülkemizde de eğitim hayatlarına devam ettiklerini düşündürmektedir (Şekil 4).

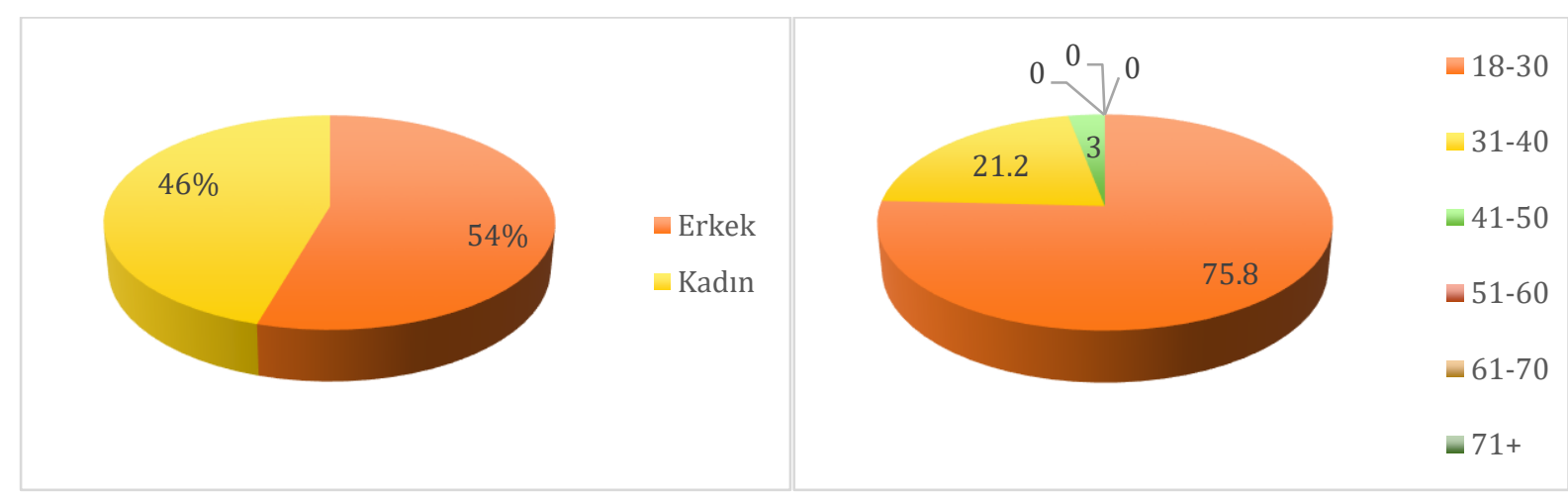

Şekil 1. Cinsiyet

Şekil 2. Yaş Aralığı 


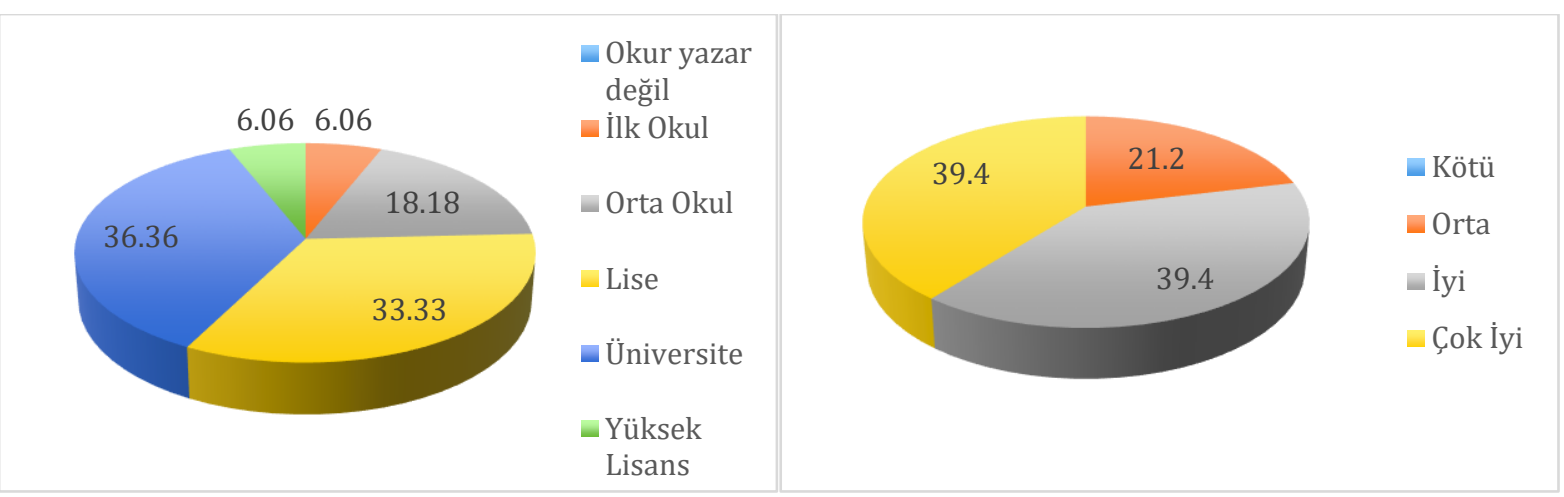

Şekil 3. Eğitim Durumu

Şekil 4. Türkçe Yeterlilik Seviyesi

Tablo 1'e göre cinsiyete göre eğitim düzeyi incelendiğinde erkeklerin $\% 55,55$ oranında üniversite ve lisansüstü eğitim aldığı gözlenmiştir. Buna karşın kadınların \%66 'sının ortaokul ve lise eğitimi almış olmaları araştırma evren ortalamasının üzerindedir. 2011 yılından bu yana ülkemizde Suriyeli göçmenlere yönelik verilen eğitimlerin de bu oranların yükselmesinde etkisinin olduğu söylenebilir. Katılımcılar arasında okur- yazar olmayan bulunmamaktadır.

Araştırma grubunun \% 45,5 'i evli olduğunu, \% 51,5 'i bekâr olduğunu ve \% 3' ü ise boşanmış-dul olduğunu belirtmişlerdir. Katılımcıların \%79 'unun 4 ve üzeri aile bireyi ile beraber yaşaması (Şekil 5) ve \% 80,5 inin kendi evlerinde ve ya akrabaları ile yaşıyor olmaları aileleri ile beraber göç ettikleri sonucuna varmamızı sağlamaktadır. Fakat buna karşın Türkiye'de herhangi bir işte çalışma oranlarının çok düşük olması endişe vericidir (Şekil 6) . Suriye'de mesleği bulunanların $\% 92$ 'si Türkiye'de herhangi bir işte çalışmamaktadır.

Tablo 1. Cinsiyete Göre Eğitim Durumu

\begin{tabular}{llllllll}
\hline \multicolumn{7}{c}{ Eğitim Düzeyi } \\
\hline Cinsiyet & $\begin{array}{l}\text { Okur-Yazar } \\
\text { Değil }\end{array}$ & Illkokul & Ortaokul & Lise & Üniversite & Lisansüstü & Toplam \\
\hline \multirow{2}{*}{ Kadın } & 0 & 1 & 5 & 5 & 3 & 1 & 15 \\
$\%$ & 0 & 6,66 & 33,33 & 33,33 & 20 & 6,66 & 100 \\
Erkek & 0 & 1 & 1 & 6 & 9 & 1 & 18 \\
$\%$ & 0 & 5,55 & 5,55 & 33,33 & 50 & 5,55 & 100 \\
Toplam & 0 & 2 & 6 & 11 & 12 & 2 & 33 \\
$\%$ & 0 & 6,06 & 18,18 & 33,33 & 36,36 & 6,06 & 100 \\
\hline
\end{tabular}

İşsizlik oranının yüksek olmasına rağmen \%48,5 'i gelecekte Türkiye'de yaşamayı istemektedir (Şekil 7). Türkiye'deki yaşadıkları bölgeyi \%79 oranında güvenli bulmakta ve Türkiye'den beklentilerinin kısmen karşılandığını belirtmektedirler. Türkiye'de ne kadar kalacaklarına dair düşüncelerini belirlemeye yönelik soruda ise yarıdan fazlasının $(\% 60,6)$ hep kalmak istemesi, göç edilen yerde kalma süresi ile kalma isteğinin doğru orantılı arttığı hipotezini güçlendirmektedir. Şartlar normale dönünce Suriye 'ye dönmek isteyenlerin oranı ise \%21,2 'de kalmıştır (Şekil 8). 


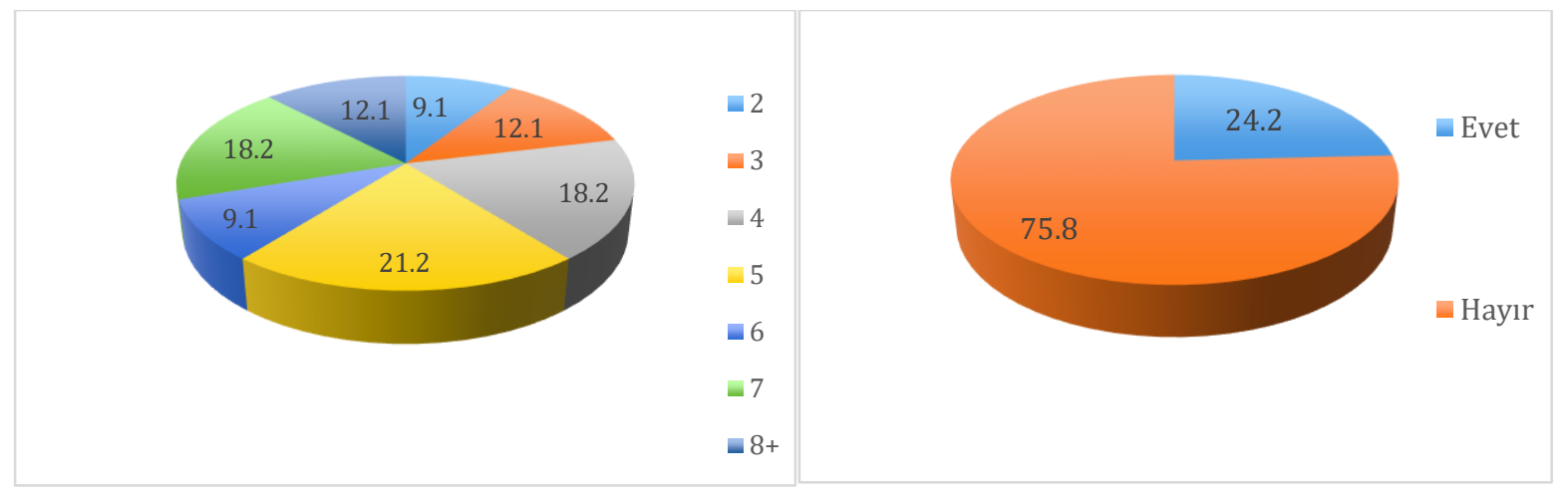

Şekil 5. Ailedeki Kişi Sayısı

Şekil 6. Türkiye 'deki Çalışma Durumu

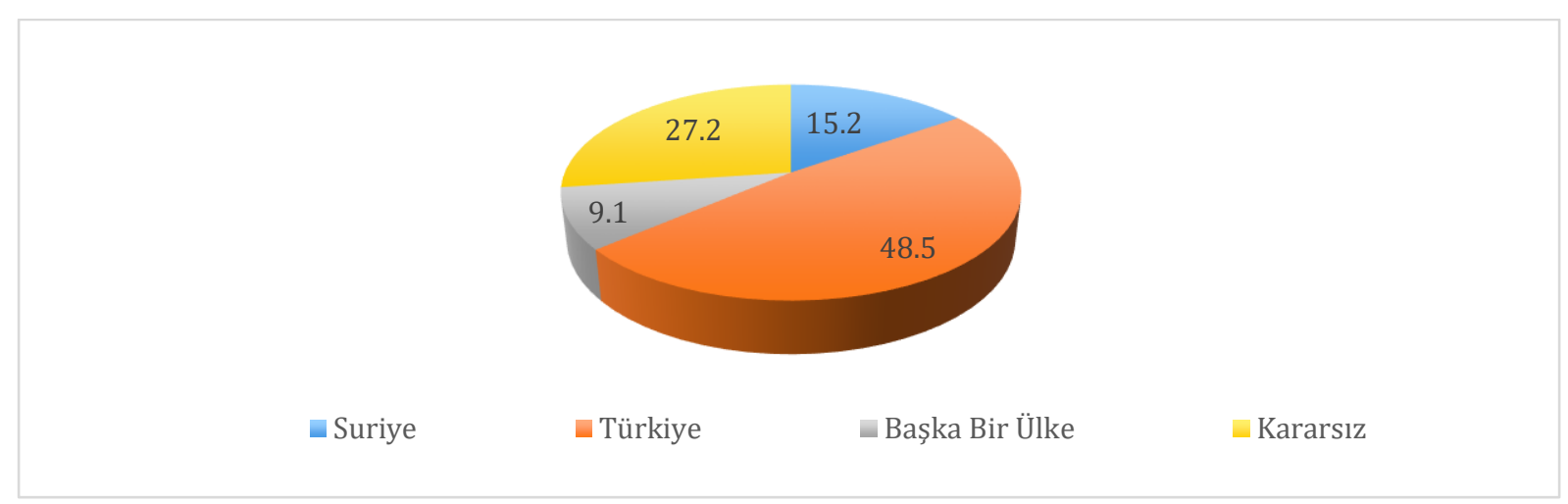

Şekil 7. Gelecekte Yaşamak İstenilen Ülke Bilgisi

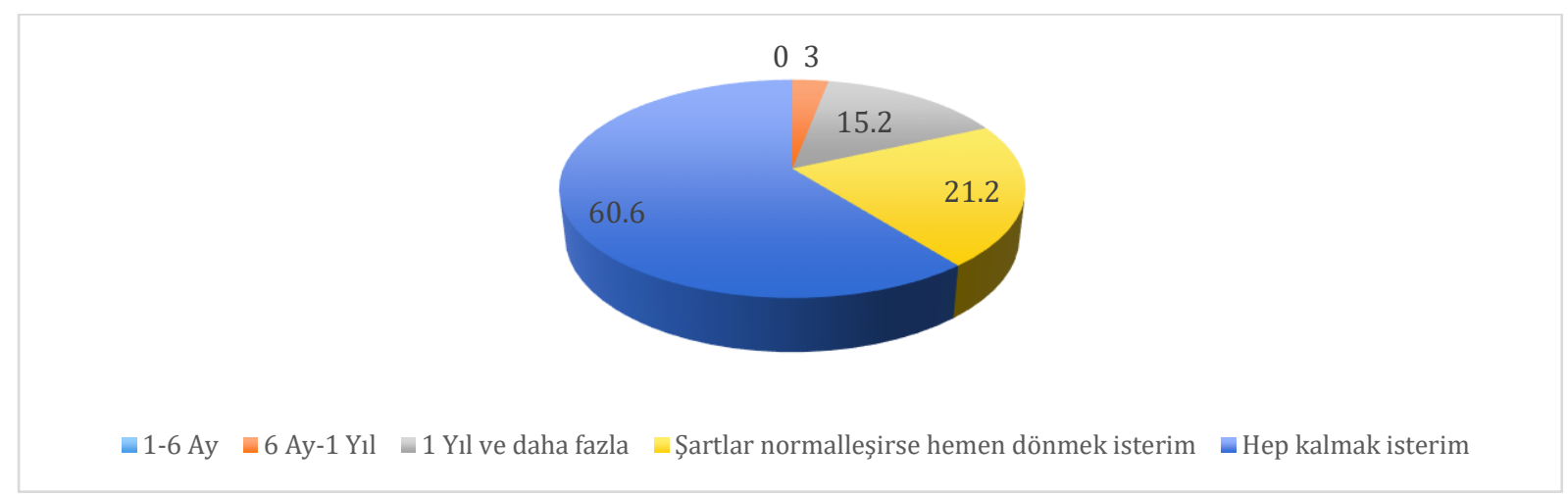

Şekil 8. Türkiye’de Ne Kadar Kalacă̆ı Bilgisi

Kendi evinde ve akrabalarının yanında yaşayanların çoğu yaşadıkları bölgede çoğunlukla $(\% 63,6)$ Türklerin bulunduğunu belirtmiștir (Şekil 9). Türklerle uyum sorularında genellikle sorun yaşamadıklarını belirtmeleri katılımcıların toplumsal uyumu sağladıklarını düşündürmektedir. Aynı şekilde Türklerin kendilerine bakış açılarının olumsuz olmadığını ve çocuk sahibi olanların çocukları ile Türk çocuklarının uyum sorunu yaşamadığını belirtmişlerdir (Şekil 10).

Afet bilincinin ölçülmesinin hedeflendiği soruda katılımcıların \%27,3 yaşadığı bölgenin afet risklerini bildiğini, \%33,3' ü “kısmen” bildiğini ve \%39,4' ü ise bilmediğini belirtmiştir (Şekil 11). Yaşanılan bölgenin afet risklerinin bilinirliğinin aksine katılımcıların \% 48,5 'u afet anında yapılması gerekenleri bildiğini, \%36,4' ü "kısmen" bildiğini, \%15,2 'si bilmediğini belirtmiştir. Afet anında yapılması gerekenleri bildiğini belirtenlerin yarıdan fazlası $(\% 53,84)$ yaşadığı bölgenin afet risklerini bilmemektedir ( Şekil 12). 


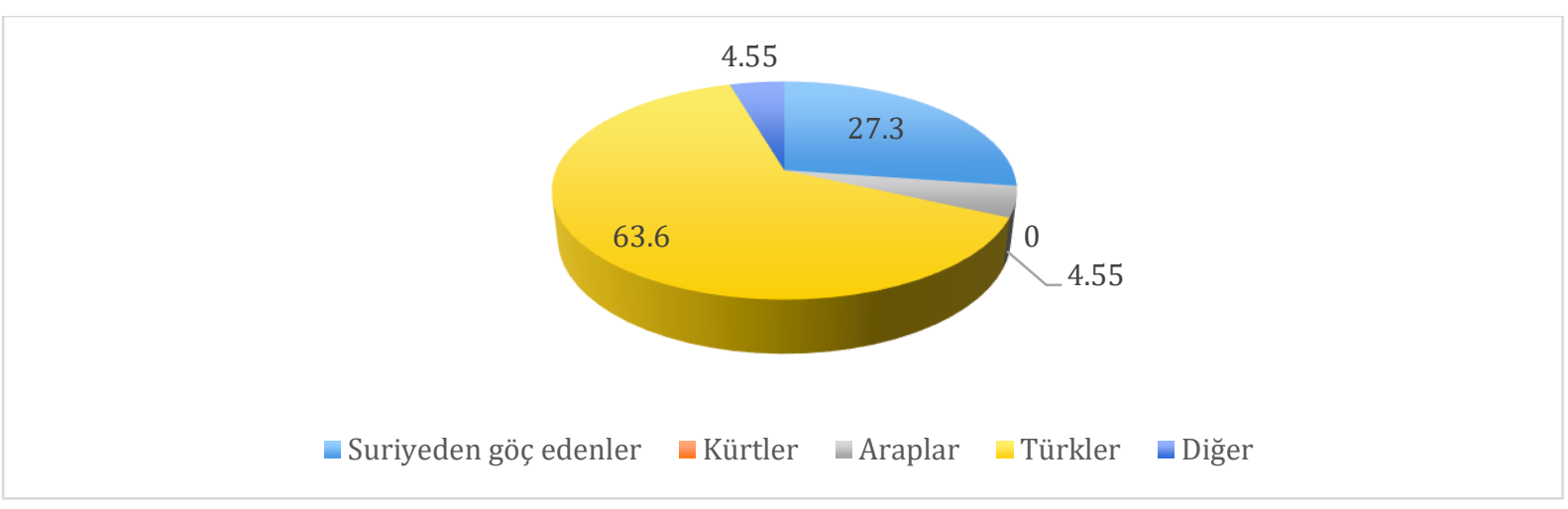

Şekil 9. Yaşanılan Bölgedeki Yoğunluk Durumu

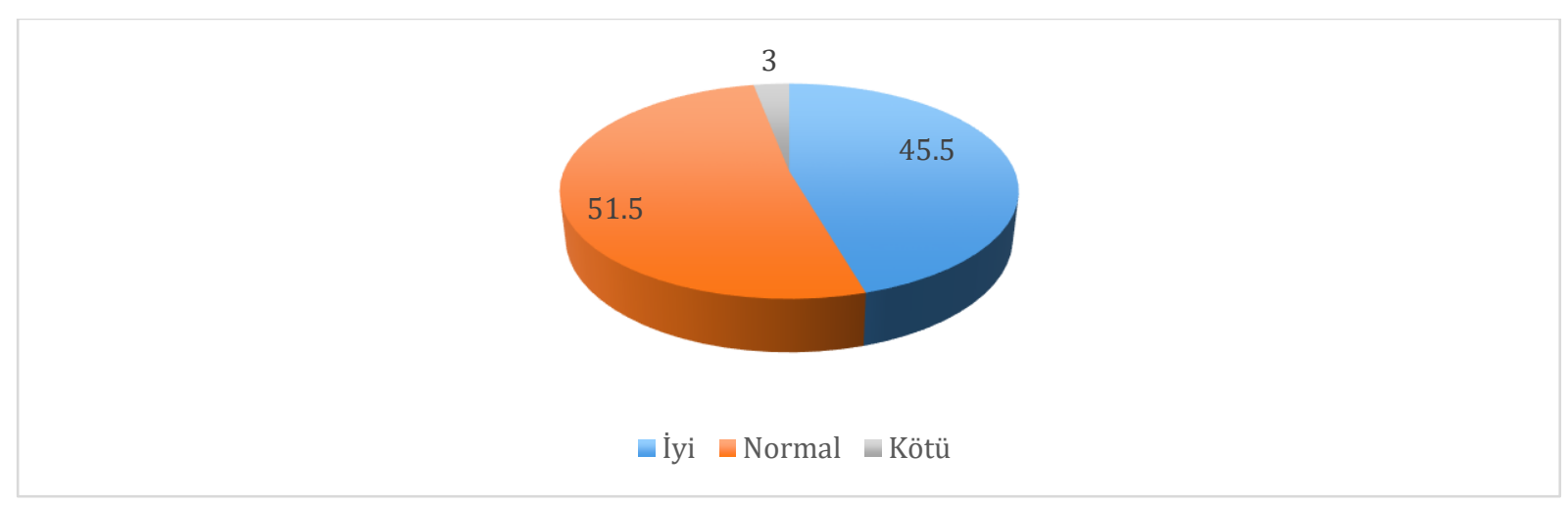

Şekil 10. Türklerin Suriyeli Göçmenlere Bakışı

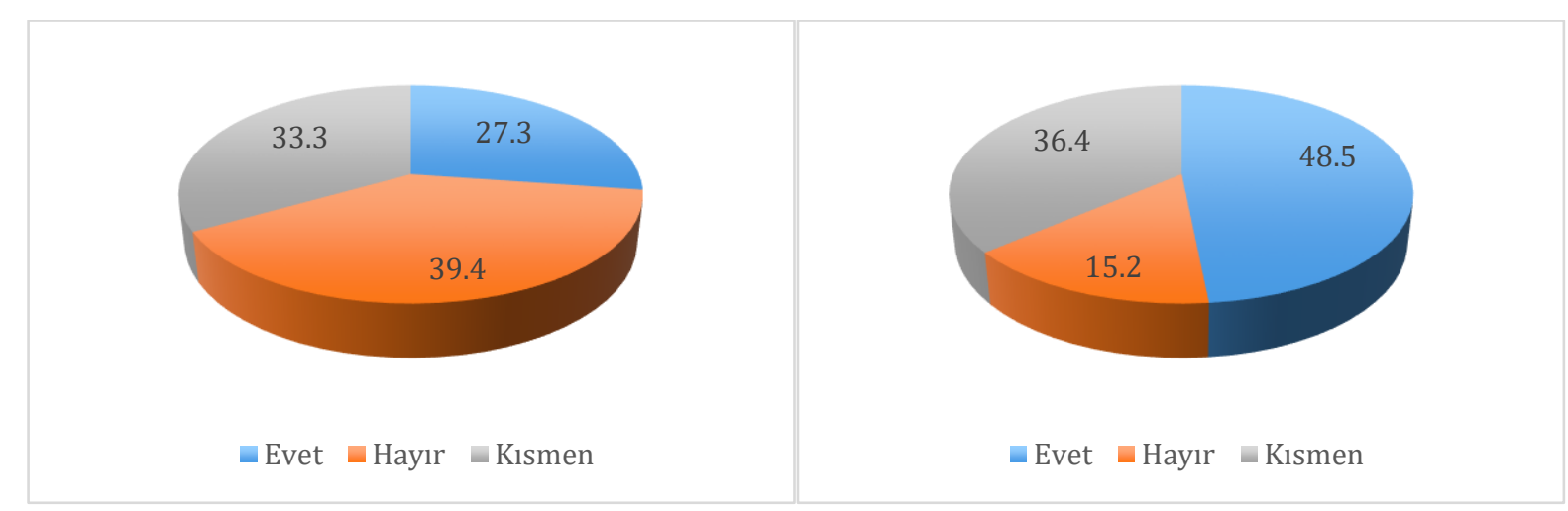

Şekil 11. Yaşanılan Bölgenin Afet Risk

Bilgi Düzeyi
Șekil 12. Afet Durumunda Yapılması Gerekenler Bilgi Düzeyi

Tablo 2 'de yaşam alanı kriterlerinin ağırlıklandırılmasına yer verilmiştir. Ankette derecelendirme sorusu olarak yer almakta ve yaşam alanlarında en çok tercih edecekleri kritere 1, en az tercih edecekleri kritere 7 puan vermeleri istenmiştir. Sonuçlar yaşam alanlarında en çok tercih edilenin en az puan almasına göre sıralanmıştır. Bu nedenle 2.1 puan ile ilk sırada güvenlik beklentisinin bulunması savaşın kendilerinde yarattığı travmanın ne denli güçlü olduğunu göstermektedir. 3.6 puan ile iş/ iş olanaklarına yakın olması tercihinin 2. sırada yer alması işsizliğin yaygın olduğunun 
bir diğer göstergesidir. 3.8 puan ile yaşam alanının afet bölgesinde olmaması kriterinin 3. sırada tercih edilmesinin afet anında yapılması gerekenler bilinç düzeyinin yüksek olması ( $\% 48,5)$ ile ilişkili olabileceğini düşündürmektedir. Buna rağmen katılımcıların \%40' 1 yaşadıkları bölgenin afet risklerini bilmediğini ifade etmektedir. Afet bölgesinde olmaması ile aynı puanı alan yaşam alanının okullara yakın olması seçeneği eğitim hayatlarının Türkiye 'de halen devam ettiği düşüncesini pekiştirmektedir. Ayrıca yaşam alanlarının hastanelere yakın olması seçeneğinin 4.3 puan ile 5. sırada tercih edilmesinin ücretsiz sağlık hizmeti almalarına rağmen yakın olmasını isteyecek kadar sıklıkta hastaneye gitmediklerini düşündürmektedir. Sosyal ve kültürel alanlara yakınlığın 5 puan ile 6. Sırada yer alması gelirlerinin çok düşük olması nedeniyle sosyal -kültürel alanlarda vakit geçiremediklerini düşündürmektedir. Yaşam alanı kriterlerinde 5,07 puan ile son olarak akrabalarına yakın olmayı tercih etmeleri Türkiye'deki yaşama ayak uydurduklarını, birey olarak kendilerini ifade edebildiklerini, iletişim sorunu yaşamadıklarını ve Suriyeli akrabaları ile telefon, sosyal medya vb. gibi araçlarla sıklıkla iletişimde oldukları için fiziken bir arada bulunma ihtiyacı taşımadıkları sonucuna varabiliriz.

Tablo 2. Yaşam Alanı Kriterlerinin Ağırlıklandırılması

\begin{tabular}{|c|c|c|c|c|c|c|c|c|c|c|c|c|c|c|c|c|c|}
\hline 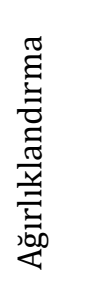 & 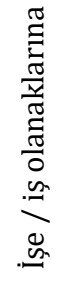 & 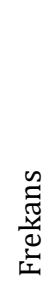 & 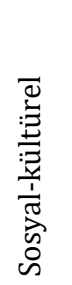 & $\begin{array}{l}\frac{\Xi}{\pi} \\
\stackrel{\pi}{\pi} \\
\frac{\pi}{\pi} \\
\frac{\pi}{\pi} \\
\frac{\pi}{\pi}\end{array}$ & 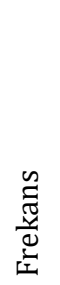 & 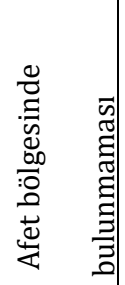 & 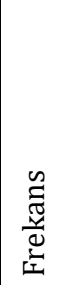 & 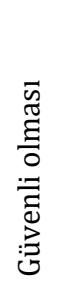 & 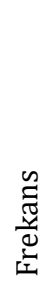 & 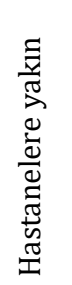 & 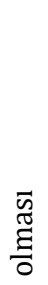 & 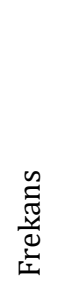 & 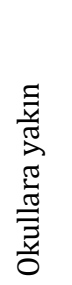 & 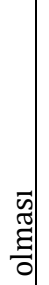 & 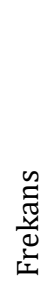 & 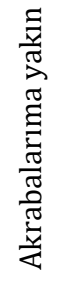 & $\begin{array}{l}\stackrel{2}{\pi} \\
\frac{\pi}{d} \\
d\end{array}$ \\
\hline 1 & 4 & 4 & 2 & & 2 & 5 & 5 & 16 & 16 & 4 & & 4 & 4 & & 4 & 4 & 4 \\
\hline 2 & 5 & 10 & 1 & & 2 & 5 & 10 & 2 & 4 & 1 & & 2 & 3 & & 6 & 3 & 6 \\
\hline 3 & 5 & 15 & 4 & & 12 & 2 & 6 & 4 & 12 & 3 & & 9 & 4 & & 12 & 0 & 0 \\
\hline 4 & 4 & 16 & 3 & & 12 & 4 & 16 & 0 & 0 & 3 & & 12 & 6 & & 24 & 1 & 4 \\
\hline 5 & 2 & 10 & 1 & & 5 & 2 & 10 & 2 & 10 & 8 & & 40 & 4 & & 20 & 3 & 15 \\
\hline 6 & 2 & 12 & 8 & & 48 & 4 & 24 & 1 & 6 & 3 & & 18 & 2 & & 12 & 2 & 12 \\
\hline 7 & 4 & 28 & 7 & & 49 & 4 & 28 & 1 & 7 & 4 & & 28 & 3 & & 21 & 13 & 91 \\
\hline Toplam & 26 & 95 & 26 & & 130 & 26 & 99 & 26 & 55 & 26 & & 113 & 26 & & 99 & 26 & 132 \\
\hline $\begin{array}{l}\text { Ağırlık } \\
\text { puanı }\end{array}$ & $\begin{array}{l}3,6 \\
54\end{array}$ & & 5,000 & & & 3,808 & & 2,115 & & 4,346 & & & 3,808 & & & 5,077 & \\
\hline
\end{tabular}

Türkiye'de kalmak isteyenlerin \%71 'i temel ihtiyaçlarının (sağlık, eğitim, barınma vb. gibi ) karşılanması, iş olanakları sunulması gibi seçeneklerin bulunmasına rağmen kendilerine Türk vatandaşlığının verilmesini tercih etmeleri gelecekte kendilerinin ve çocuklarının hak ve statülerini yasal olarak garantiye almak istemeleri ile ilişkilendirilebilir (Şekil 13). Sadece \%9 'luk kısmının başka bir ülkede yaşamak istemesini belirtmesi yaş ortalaması genç olmasına rağmen araştırma grubumuzun Avrupa hayallerinin bulunmadığını göstermektedir. Avrupa'ya göçmen kabulünde çok fazla prosedürün bulunması ve yasa dişı yollarda yaşanılan dramların Suriyeli göçmenlerde Avrupa umudunun azalmasına neden olmuştur.

Yaşam alanı kriterlerinin belirlenmesini amaçladığımız çalışmamızda araştırma grubumuzun en büyük sorununun güvenlik ve ekonomik sıkıntılar olduğundan bahsedebiliriz. Türklerle beraber yaşamanın sorun teşkil etmediği ve tek taraflı da olsa toplumsal uyumun tamamlandığı da gözlemlenmektedir. Eğitim düzeyinin yüksek olması ve yaşam alanı kriterleri tercihinde okullara 
yakınlığın 3. sırada tercih edilmesi de eğitime verilen önemin giderek arttığını göstermektedir. Katılımcların yarısından fazlasının (\% 51) bekâr olması eğitim düzeyi ile beraber evlenme yaşının da arttığını göstermektedir. Aynı zamanda Türklerin yoğun yaşadığı bölgelerin Suriyeli göçmenler tarafından daha çok tercih edilmesinin bir diğer doğal sonucu olarak Türk-Suriyeli evliliklerin gelecekte olma olasılığını da arttırmaktadır.
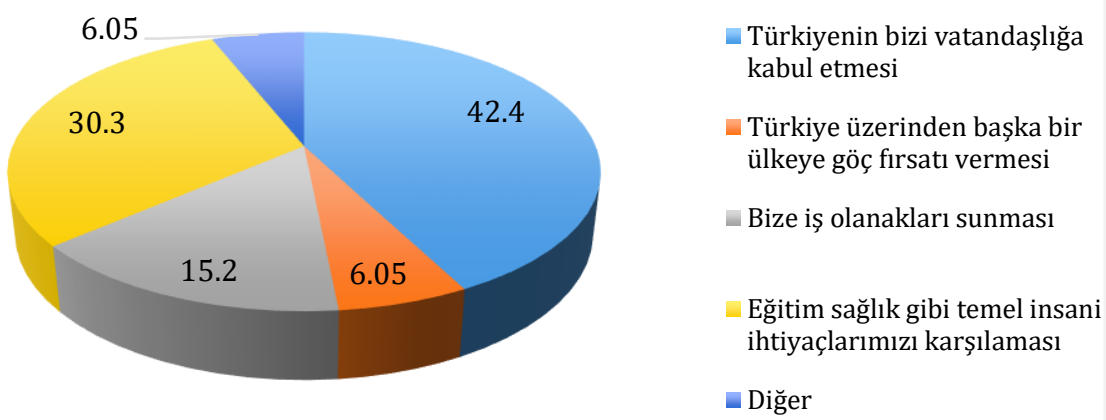

Șekil 13. Türkiye 'den Beklentiler

\section{SONUÇLAR}

Son yüzyılın en büyük kitlesel göçü olarak adlandırılan Suriyeli göç dalgasının onbirinci yılında Türkiye 'de geçirilen sürenin uzaması ülkelerinde savaş ve iç karıșılklı bitse bile geri dönme arzularının azalmasına neden olmaktadır. Amerika ve Avrupa Birliğinin göç politikalarındaki 11 Eylül saldırıları sonrasında yapılan köklü değişiklikler, Suriyeli göçmen nüfus için üçüncü bir ülkede yaşam hayallerinin de tükenmesine neden olmaktadır. Türkiye'nin yaklaşık \%4,4'ünü oluşturan Suriyelilerin yaşam alanlarına odaklanılan bu çalışmada artık kamplardaki yaşamın sonuna gelindiği gözlemlenmektedir. Bu nedenle Türkiye'nin her kentinde dağınık halde yaşayan Suriyeliler için yaşam alanları kriterlerlerinin belirlenmesini amaçlayan anket çalışması yapılmıştır. Yaşam alanlarının belirlenmesinde ekonomik, sosyal ve kültürel ihtiyaçlarla güvenlik ve afetsellik kriterleri göz önünde bulundurulmuştur.

Büyük kentlerde kendi evlerinde veya akrabalarının yanında ve genellikle Türklerin bulundukları bölgelerde yaşamayı tercih eden Suriyelilerin en büyük sıkıntısı ekonomik anlamdadır. Mesleki eğitim eksikliği, dil sorunu ve çalışma izinlerinin bulunmaması Suriyelileri kayıt dışı, göreceli olarak kötü koşullarda ve daha az gelirle çalışmaya itmektedir. Bu durum yaşam alanlarını metropollerin yoksul mahallerinde seçmeye zorlamaktadır. Türkiye ekonomisi üzerinde işsizlik, yoksulluk, kayıt dışılık ve ucuz emek gücü olarak yük oluşturan mevcut durumun iyileştirilmesi için Avrupa Birliği ve Türkiye'nin geliştireceği politikalar önem arz etmektedir. Suriyelilerin yoğun yaşadığı Ürdün ve Lübnan örneklerinde olduğu gibi Avrupa Birliği ile ortak yürütülen "Organize Sanayi Bölgeleri Projeleri”, Türkiye'nin özellikle büyük sanayi kentlerinde geliştirilebilir. Yabancı yatırımcılar ve yurtiçi girişimciler için en az \%15 Suriyeli göçmen istihdam etmesi şartının yerine getirilmesi şartı ile Avrupa ortak pazarına imtiyazlı erişim hakkı sağlayan bu proje Türkiye'de uygulanması durumunda Suriyelilerin ekonomik sorunlarına çözüm olması açısından alternatif oluşturabilmektedir.

Ayrıca Türkiye'de yaşayan Suriyelilerin sağlık ve eğitim ihtiyaçlarının karşılandığı fakat güvenlik beklentilerinin yüksek olması savaşın yarattığı travmaların etkilerinin devam ettiğini göstermektedir. $\mathrm{Bu}$ açıdan Türklerin yoğun yaşadığı güvenli bölgelerde yaşam alanlarının belirlenmesi, gettolaşmanın engellenmesi ve sosyal uyum için önem taşımaktadır. 
Türkiye'deki Suriyeli Göçmen Nüfus İçin Yaşam Alanı Seçimi

\section{KAYNAKLAR}

Birleşmiş Milletler Mülteci Ajansı, UNHCR.https://www.unhcr.org/tr/turkiyedeki-multeciler-vesiginmacilar. (Son Erişim: 15.12.2020).

Birleşmiş Milletler Mülteci Ajansı, UNHCR. https://www.unhcr.org/syria-emergency.html (Son Erişim: 15.12.2020).

Birleşmiş Milletler Mülteci Ajansı, UNHCR. https://www.unhcr.org/figures-at-a-glance.html. (Son Erişim: 20.12.2020).

Baykal, S. ve Yllmaz, L.(2020). Yabancılar ve Uluslararası Koruma Kanunu ile Göç İdaresi Bağlamında Türkiye'nin Yeni Göç Siyaseti, Optimum Ekonomi ve Yönetim Bilimleri Dergisi, 7 (2), s. 633 - 652.

Çalışkan, A. (2020). Geçici Koruma Kapsamındaki Suriyelilerin Mekân Tercihlerinde Rasyonelliğin Analizi. Dokuz Eylül Üniversitesi Sosyal Bilimler Enstitüsü Dergisi, 22( 3), s. 1189-1204.

Efe, H. (2018). Osmanlı İmparatorluğu ve Türkiye'de Yaşanan Göçler ve Etkileri, Sosyal Bilimler Metinleri, $2018(1), 16-27$.

International Displacement Monitoring Centre, IDMC. https://www.internaldisplacement.org/publications/unveiling-the-cost-of-internal-displacement-0 (Son Erişim: 15.12.2020).

Lustgarten, A. (2020). The Great Climate Migration Has Begun, The New York Times.

MEB Hayat Boyu Öğrenme Genel Müdürlüğü. https://hbogm.meb.gov.tr/meb iys dosyalar/2019 10/02101034 09Eylul 2019 internetSunumu .pdf (Son Erişim: 02.01.2021).

Mültecilerle Dayanışma Derneği .(2019). Mültecilerin Hukuki Statüsüne İlişkin Sözleşme. https://www.multeci.org.tr/wp-content/uploads/2016/12/1951-Cenevre-Sozlesmesi-1.pdf (Son Erişim: 20.12.2020).

Mülteciler Derneği. https://multeciler.org.tr/tag/iom/ (Son Erişim: 02.01.2021).

Orhan, O. ve Gündoğar, S. (2015). Suriyeli Sığınmacıların Türkiye’ye Etkileri. Ortadoğu Araştırmaları Merkezi.

T.C. Göç İdaresi Genel Müdürlüğü. (2020, Aralık). Geçici Koruma. https://www.goc.gov.tr/gecicikoruma5638 (Son Erişim :20.12.2020).

T.C. Göç İdaresi Genel Müdürlüğ̈u. https://www.goc.gov.tr/genelbilgi45 (Son Erişim: 20.12.2020).

T.C. Göç İdaresi Genel Müdürlüğü.https://www.goc.gov.tr/goc-tarihi(Son Erişim: 20.12.2020).

T.C. Göç İdaresi Genel Müdürlüğ̈̈. https://www.goc.gov.tr/gecici-koruma5638 (Son Erişim:15.12.2020).

Tuncel, G. ve Ekici, S. (2019). Göçün Siyasal Etkisi: Suriyeli Göçmenlerin Türkiye Siyasetine Etkisi, Birey ve Toplum Dergisi, 2019( 9), s. 18.

Tuncel, G. ve Ekici, S. (2015). Göç ve İnsan, Birey ve Toplum Dergisi, 2015 (5) , s: 9.

Uluslararası Göç Örgütü. https://www.iom.int (Son Erişim: 02.12.2020).

Uluslararası Göç Örgütü. https://publications.iom.int/books/world-migration-report-2020-turkishchapter-2 (Son Erişim: 15.12.2020).

Varol, N. ve Gültekin, T. (2016) .Etkin Bir Göç faktörü: Afetler. Antropoloji Dergisi, 2016 (32) , s. 43-51. 